\title{
THERMAL DESCRIPTION OF HYPOEUTECTIC AI-Si-CU ALLOYS USING SILICON EQUIVALENCY
}

\author{
Djurdjevic B. Mile, Nemak Europe $\mathrm{GmbH}$, \\ Frankfurt, Germany \\ FIELD: Chemical Technology, Materials Science \\ ARTICLE TYPE: Original Scientific Paper
}

\begin{abstract}
:
The modeling of casting processes has remained a topic of active interest for several decades, and availability of numerous software packages on the market is a good indication of the interest that the casting industry has in this field. Most of the data used in these software packages are read or estimated from the binary or multi-component phase diagrams. Unfortunately, except for binary diagrams, many of ternary or higher order phase diagrams are still not accurate enough. Having in mind that most of the aluminum binary systems are very well established, it has been tried to transfer a multi-component system into one well known Al-Xi pseudo binary system (in this case the Al-Si phase diagram was chosen as a reference system). The new Silicon Equivalency ( $\left.\mathrm{Si}_{E Q}\right)$ algorithm expresses the amounts of major and minor alloying elements in the aluminum melts through an "equivalent" amount of silicon. Such a system could be used to calculate several thermo-physical and solidification characteristics of multi component as cast aluminum alloys. This lends the model the ability to make predictions of solidification characteristics of cast parts, where cooling rates are slow and the solidification process has to be known in great detail in order to avoid problems in the casting. This work demonstrates how the $S i_{E Q}$ algorithm can be used to calculate characteristic solidification temperatures of the multi-component hypoeutectic Al-Si-Cu alloys as well as their latent heats. SA statistical analysis of the results obtained for a wide range of alloy chemical compositions shows a very good correlation with the experimental data and the $S i_{E Q}$ calculations.
\end{abstract}

Key words: (regular): Al-Si-Cu Alloys, Silicon Equivalency, Binary Phase Diagrams, Liquidus Temperature, Eutectic Temperatures.

\section{Introduction}

The modeling and control of casting processes has remained a topic of active interest for several decades, and the availability of numerous software packages (Magma[1], Thermo-Calc[2], Fact-Sage[3], Pro- 
Cast[4], Calphad[5], Pandat[6], WinCast[7] etc.) on the market are a good indication of the interest that casting industries and researchers have in this field. Most of the data used in the above listed software packages are based on binary or multi-component phase diagrams but unfortunately; except for binary diagrams, many of ternary or higher order phase diagrams are still not accurate enough for this purpose. Keeping in mind that most aluminum binary systems are very well established, the transferring of a multi-component system into a well known Al-Xi "quasi-binary" system has a great industrial and research potential. This type of system could be used to calculate several thermo-physical and solidification process parameters of multi component aluminum alloys in either cast or melt treated conditions. In order to calculate the various thermo-physical and metallurgical parameters of solidifying aluminum casting alloys, the characteristic solidification temperatures of the alloy must be known with the highest possible degree of accuracy. Unfortunately, few equations are reported in the literature that relates the compositions of many commercially important hypoeutectic aluminum-silicon-copper series of alloys to their liquidus $[8,9,10]$ and eutectic [11] temperatures.

The cast hypoeutectic aluminum-silicon-copper alloys are widely used in many automotive components. These alloys are characterized by their low density, light weight, relative low melting temperatures, negligible gas solubility (with the exception of hydrogen) excellent castability, good corrosion resistance, electrical and thermal conductivity and good machinability. The major alloying elements; silicon, copper and magnesium, are primarily responsible for defining the aluminum alloy microstructure. Silicon is added to improve castability, fluidity, as well as to reduce shrinkage and to give superior mechanical properties. The presence of copper improves tensile strength at the expense of a reduction in ductility and corrosion resistance. Magnesium is purposely added into aluminum alloys to increase their hardness and strength after heat treatment. Manganese controls the intermetallic form of iron phase, leading to improve ductility, strength at high temperature and casting soundness. Iron is a major impurity element in this type of aluminum alloys. Its higher content decreases the ductility, castability and machinability of aluminum alloys. Minor alloying elements such as $\mathrm{Sr}, \mathrm{Na}, \mathrm{B}, \mathrm{Ti}$ and $\mathrm{Sb}$ are intentionally added into aluminum melt to improve structural and mechanical properties of cast parts. All these major and minor alloying elements have a significant impact on the solidification path of particular aluminum alloys.

The Al-Si phase diagram is the base component system for this series of alloys. This is a binary eutectic type phase diagram with limited aluminum and silicon solubility. The solubility of silicon in the aluminum melt reaches a maximum of $1.6 \mathrm{wt} \%$ at the $577^{\circ} \mathrm{C}$ eutectic temperature. The maximum solubility of aluminum in silicon at the eutectic temperature is still questionable, and according to some literature data is approx. 0.015\% [12]. The concentration of silicon, which corresponds to the eutectic reaction, is still not accurately defined or accepted among researchers, despite the 
fact that this diagram has often been investigated. In the available literature the following values for eutectic concentration of silicon were found: $11.9 w t . \%[13], 12.3 w t . \%$ [14] and 12.6wt.\% [12]. In this work the value of $12.3 \mathrm{wt} \%$ of Si will be used as the eutectic concentration of silicon as well as $577^{\circ} \mathrm{C}$ as the temperature at which eutectic reaction occurs.

The purpose of this paper is to develop a general method for the calculation of the characteristic solidification temperatures (liquidus temperature, Al$\mathrm{Si}$ and Al-Si-Cu eutectic temperatures) of multi-component hypoeutectic aluminum-silicon copper alloys, based on their known chemical compositions. The accuracy of the developed algorithms will be determined by comparing the calculated values of the characteristic solidification temperatures with the measured values obtained using the thermal analysis technique. In addition, the various software packages will be used to calculate characteristic solidification temperatures and the obtained results will be compared with the calculated temperatures determined using the SiEQ procedure. The applicability of the equivalency algorithm to calculate some other thermo-physical properties (latent heat) of aluminum alloys will be also briefly discussed in this paper.

\section{Development of the Silicon Equivalent $\left(\mathrm{Si}_{\mathrm{EQ}}\right)$ Algorithm}

The liquidus and solidus temperatures of the Al-Si phase diagram decrease uniformly with the increase in the amount of silicon and reach the minimum at the eutectic composition (12.3wt.\%). The same behavior can be observed in the liquidus and solidus lines in most binary eutectic types of aluminum alloys as presented in Fig. 1[15].

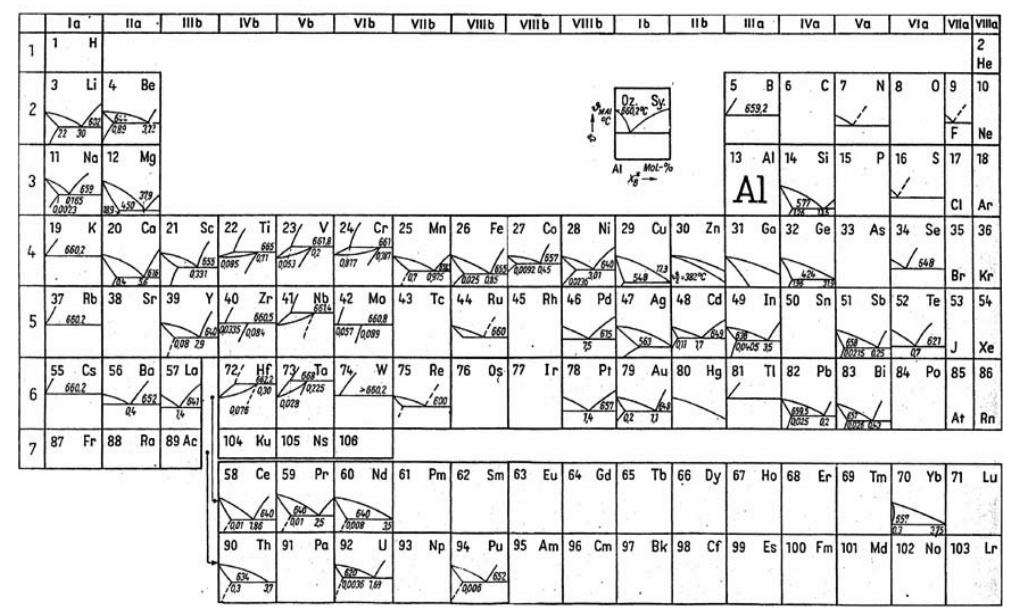

Figure 1 - Al-Xi binary phase diagram [15] Slika 1 - Al-Xi binarni fazni dijagram [15] 
Mathematically, the liquidus line of any eutectic binary Al-Xi phase diagrams from Fig. 1 can be accurately expressed by the second order polynomial as follows:

$$
\mathrm{T}_{\text {LIQ }}^{\mathrm{Al}-\mathrm{Xi}}=\mathrm{A}-\mathrm{B} \cdot \mathrm{Xi}-\mathrm{C} \cdot \mathrm{Xi}^{2}
$$

where:

$\mathrm{T}^{\mathrm{Al}-\mathrm{Xi}}{ }_{\mathrm{LIQ}}$ is the liquidus temperature of the binary $\mathrm{Al}-\mathrm{Xi}$ system, ${ }^{\circ} \mathrm{C}$

$\mathrm{Xi}$ is the amount of the alloying element in wt.\%.

$A$ is the melting point of pure aluminum: $660.452^{\circ} \mathrm{C}$.

$B, C$, are polynomial coefficients.

Therefore, the liquidus line for the Al-Si binary system can be expressed respectively as follows:

$$
\mathrm{T}_{\text {LIQ }}^{\mathrm{Al}-\mathrm{Si}}=660.452-6.11 \cdot \mathrm{Si}-0.057 \cdot \mathrm{Si}^{2}
$$

The visual analysis of two liquidus lines of the binary systems, Al-Si and $\mathrm{Al}-\mathrm{Xi}$ as presented in Fig. 2, shows that the "equivalent effect" on the liquidus temperature of the aluminum alloy can be obtained by using "equivalent" concentrations of Si and Xi alloying elements.

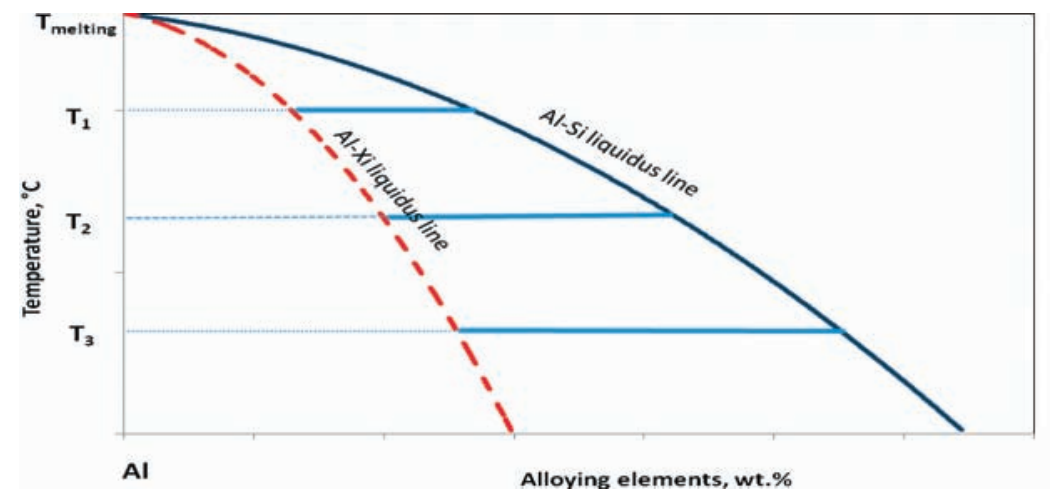

Figure 2 - Superimposed liquidus lines of Al-Si and $\mathrm{Al}-\mathrm{X}_{i}$ binary systems Slika 2 - Superponirane likvidus linije za Al-Si i Al-Xi binarne sisteme

This means that the influence of any alloying element in the aluminum melt on its liquidus temperature can be expressed as the effect of an "equivalent amount" of silicon (wt\%). The isothermal concentration difference between the Si and Xi alloying elements can be mathematically expressed as follows:

$$
\mathrm{Si}_{\text {EQ, }}^{\mathrm{X}} @ \mathrm{~T}=\text { CONSTANT }=\mathrm{Si}(\mathrm{wt} \%)-\mathrm{Xi}(\mathrm{wt} \%)
$$

Silicon as a major alloying element for hypoeutectic Al-Si-Cu series of alloys was chosen as the reference element. It is also known to have the most significant influence on the casting properties of Al-Si-Cu family of alloys (e.g. fluidity, latent heat and shrinkage).Taking into considera- 
tion the whole temperature range between the melting temperature of pure aluminum and the eutectic temperature of an observed binary alloy, the following relationship can be established between $\mathrm{Si}^{\mathrm{Xi}_{\mathrm{EQ}}}$ and the concentration of the alloying element $\mathrm{Xi}$ :

$$
\mathrm{Si}^{\mathrm{Xi}}{ }_{\mathrm{EQ}}=\mathrm{a}_{0}{ }^{\mathrm{Xi}}+\mathrm{b}_{0}{ }^{\mathrm{Xi}} \mathrm{Xi}+\mathrm{C}_{0}{ }^{\mathrm{Xi}} \mathrm{X{ } ^ { 2 }}
$$

where:

$\mathrm{Si}^{\mathrm{Xi}}{ }_{E Q}$ is the silicon equivalent for any alloying element expressed in wt. \% $a_{0}{ }^{{ }^{i}}, b_{0}{ }^{{ }^{x i}}, c_{0}{ }^{{ }^{i}}$ polynomial coefficients for a considered alloying element $X i$ the concentration of alloying elements in wt\%

Figs. $3 \mathrm{a}$ and $3 \mathrm{~b}$ summarize the effect of some major, minor and other elements, such as impurities, grain refiners, silicon modifiers, etc. on the $\mathrm{Si}^{\mathrm{X}_{\mathrm{i}}}{ }_{\mathrm{EQ}}$. Their effect has been expressed in the polynomial form according to Eq. (4).

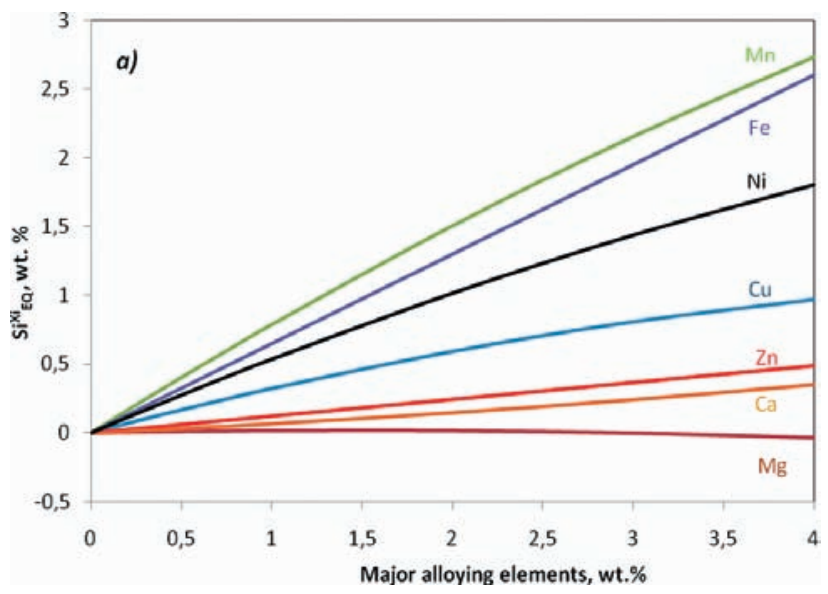

Figure $3 \mathrm{a}$ - The effect of major alloying elements on the $\mathrm{Si}^{\mathrm{Xi}}{ }_{\mathrm{EQ}}$ for hypoeutectic alloys Slika 3 a - Uticaj glavnih legirajucih elemenata na $\mathrm{Si}^{\mathrm{Xi}}{ }_{\mathrm{EQ}} \mathrm{za}$ hipoteticke legure

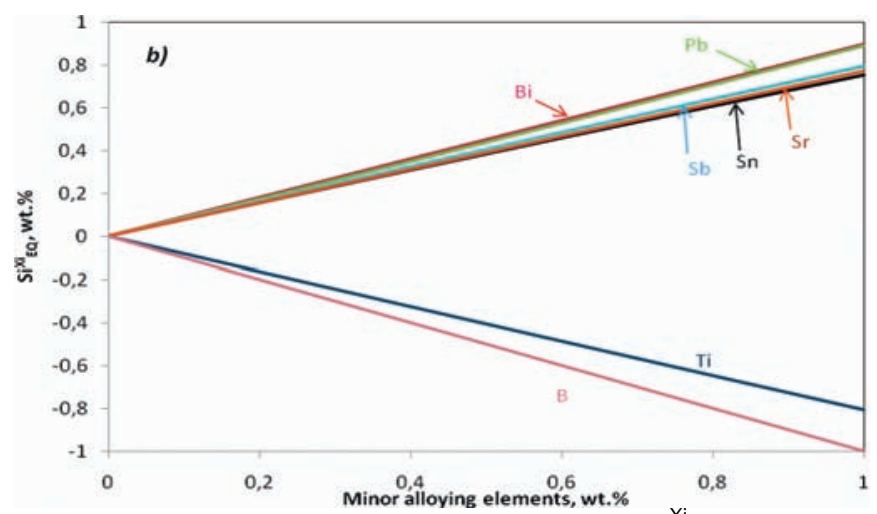

Figure $3 b$ - The effect of minor alloying elements on the $\mathrm{Si}^{\mathrm{Xi}^{\mathrm{i}}}$ for hypoeutectic alloys. Slika $3 b$ - Uticaj minornih legirajucih elemenata na $\mathrm{Si}^{\mathrm{Xi}}{ }_{\mathrm{EQ}}$ za hipoteticke legure 
Manganese $\mathrm{Mn}$ has the strongest effect on the $\mathrm{Si}^{\mathrm{Xi}}{ }_{\mathrm{EQ}}$ (Fig 3a). The effect of other major alloying elements decreases in the following order $\mathrm{Fe}, \mathrm{Ni}, \mathrm{Cu}, \mathrm{Zn}, \mathrm{Ca}$ and $\mathrm{Mg}$, respectively. This order corresponds to the slope value $(\Delta T / \Delta X i)$ of the liquidus line for a particular binary Al-Xi phase diagram. The effect of some other elements on the value of the $\mathrm{Si}^{\mathrm{X}_{\mathrm{i}}}{ }_{\mathrm{EQ}}$ has been presented in Fig. 3b. It is interesting to notice the similar effect of grain refiners ( $\mathrm{Ti}$ and $\mathrm{B}$ ), silicon modifiers ( $\mathrm{Sr}$ and $\mathrm{Sb}$ ) and low melting points elements $\left(\mathrm{Bi}\right.$ and $\mathrm{Pb}$ ) on the increase or decrease of the $\mathrm{Si}^{\mathrm{Xi}}{ }_{\mathrm{EQ}} \mathrm{Va}$ lue. The $\mathrm{Si}_{\mathrm{EQ}}$ for alloying elements as well as for some impurity elements can be determined as a sum of individual contributors $\left(\Sigma \mathrm{Si}^{\mathrm{Xi}^{\mathrm{X}}}{ }_{\mathrm{EQ}}\right)$ plus the effect of silicon itself, and can be expressed as follows:

$$
\mathrm{Si}_{\mathrm{EQ}}=\mathrm{Si}+\Sigma \mathrm{Si}^{\mathrm{Xi}}{ }_{\mathrm{EQ}}
$$

The characteristic solidification temperatures for multi component Al-Si-Cu series of alloys can be calculated using the following equations:

$$
\begin{aligned}
& \mathrm{T}^{\mathrm{Al}-\mathrm{Si}-\mathrm{Cu}-\mathrm{Si}}{ }_{\mathrm{LIQ}}=660.452-6.11 \cdot \mathrm{Si}_{\mathrm{EQ}}-0.057 \cdot \mathrm{Si}_{\mathrm{EQ}}{ }^{2} \\
& \mathrm{~T}^{\mathrm{AlSi}}{ }^{\mathrm{E}}=660.452-\left(\left(6.11 \cdot \mathrm{Si}_{\mathrm{EQ}}+0.057 \cdot \mathrm{Si}_{\mathrm{EQ}}{ }^{2}\right) \cdot 12.3 / \mathrm{Si}\right. \\
& \mathrm{T}^{\mathrm{Al}-\mathrm{Si}-\mathrm{Cu}}{ }_{\mathrm{E}}=\mathrm{T}_{\mathrm{LIQ}}-\left(6.11 \cdot \mathrm{Si}_{\mathrm{EQ}}-0.057 \cdot \mathrm{Si}_{\mathrm{EQ}}{ }^{2}\right) \cdot 12.3 / \mathrm{Si}
\end{aligned}
$$

Using the $\mathrm{Si}_{\mathrm{EQ}}$ method some other thermo-physical properties such as fraction solid and latent heat [16] can also be calculated.

\section{Literature Review of Equations for the Calculation of Characteristic Solidification Temperatures for Al- Alloys}

In the available literature a number of published equations are found for calculation of the liquidus temperature from the known chemical composition of the iron base melts. Unfortunately, there are only two published equations for calculation of the liquidus temperature, related to multi-component aluminum alloys. These equations are shown below and later will be compared with the newly developed equations based on the $\mathrm{Si}_{\mathrm{EQ}}$ algorithm. The best known equation for calculating the liquidus temperature of aluminum alloys $\left(T_{\text {LIQ }}\right)$, based on their known chemical compositions, was developed by Drossel [8] using the multiple regression analysis of the experimental data:

$\mathrm{T}_{\text {LIQ }}=661-4.97 \mathrm{Si}-0.15(\mathrm{Si})^{2}-6.13 \mathrm{Cu}-17.4 \mathrm{Mg}+2.72 \mathrm{Zn}+5.08 \mathrm{CuMg}$ 
Unfortunately, equation (9) is valid only for the following ranges of chemical compositions (expressed in wt\%); therefore, its applicability is limited:

$\mathrm{Si} \leq$ 9.30; $\mathrm{Cu} \leq 2.50 ; \mathrm{Mg} \leq 0.60 ; \mathrm{Fe} \leq 1.15 ; \mathrm{Mn} \leq 0.40 ; \mathrm{Zn} \leq 0.63 ; \mathrm{Ni} \leq 0.43 ; \mathrm{Ti} \leq 0.05$

The next equation for predicting $\mathrm{T}_{\mathrm{LIQ}}$ of aluminum alloys, for $\mathrm{Al}-\mathrm{Si}-\mathrm{Cu}$ systems, has been developed by Vijayaraghavan at al. [9]. Using the data from the ternary aluminum-silicon-copper phase diagram and applying the multiple regressions analysis, the following mathematical relation has been obtained:

$$
\mathrm{T}_{\text {LIQ }}=664-6.9 \mathrm{Si}-2.5 \mathrm{Cu}
$$

Equation 10, based on Al, Si and Cu concentrations only, fails to account for the potentially important influence of other components (for example $\mathrm{Mg}, \mathrm{Mn}, \mathrm{Fe}, \mathrm{Zn}$ and Ti); therefore, a substantial error may be involved. This is evident from the fact that the equation's constant $\left(664^{\circ} \mathrm{C}\right)$ is considerably higher than the known melting point of pure aluminum $\left(660.452^{\circ} \mathrm{C}\right)$.

The available literature provides two equations developed by Modolfo [10] and Gruzleski [11] that can be used to calculate the aluminum-silicon eutectic growth temperature of the Al-Si-Cu series of aluminum alloys. These equations are based on the effect of the chemical composition of the melt on the depression of the aluminum-silicon eutectic temperature. The effect of each particular element has been derived using literature data and the authors' own experimental data. The equations read as follows:

$\mathrm{T}^{\mathrm{AlSi}}{ }_{\mathrm{E}}=577-(12.5 / \mathrm{Si}) *(4.43 \mathrm{Mg}+1.43 \mathrm{Fe}+1.93 \mathrm{Cu}+1.7 \mathrm{Zn}+3.0 \mathrm{Mn}+4.0 \mathrm{Ni})$

$\mathrm{T}^{\mathrm{AlSi}}{ }_{\mathrm{E}}=660.452-\left(6.11 \mathrm{Si}+0.057 \mathrm{Si}^{2}\right)(12.6 / \mathrm{Si})-(3.4 \mathrm{Cu}+1.34 \mathrm{Fe}+6.3$

$\left.\mathrm{Mg}+1218.9 \mathrm{Sr}-32965 \mathrm{Sr}^{2}-4.293 \mathrm{Sb}+186.3 \mathrm{Sb}^{2}-495.5 \mathrm{Sb}^{2}\right)$,

- all the element amounts are given in weight percentages.

In the literature there are no equations for calculating the Al-Si-Cu eutectic temperature or the solidus temperature for the Al-Si series of alloys.

\section{Experimental Procedure Materials}

Twelve synthetic hypoeutectic Al-Si-Cu compositions were made by melting a charge of Al-5wt.\% Si, Al-7wt.\% Si, Al-9wt.\% Si and Al-11 wt.\% Si base alloys and adding 1, 2 and 4 wt.\% Cu. The chemical compositions of the resulting alloys, as determined using Optical Emission Spectroscopy, are shown in Tab. 1. 
Table 1 - Chemical compositions (wt.\%) of the experimental synthetic aluminum alloys and their characteristic $T_{L I Q}$ and $T^{A I S i}$ temperatures measured using the Thermal Analysis (note that only major alloying elements are summarized).

Tabela 1 - Hemijski sastavi (u tezinskim procentima) za eksperimentalne sinteticke legure aluminijuma i njihove karakteristicne legure $T_{\text {LIQ }}$ and $T^{A I S i}{ }_{E}$ merene koriscenjem termijske analize (samo glavni legirajuci elementi su ovde prikazani)

\begin{tabular}{|c|c|c|c|c|c|c|c|c|c|}
\hline Alloy & $\mathrm{Si}$ & $\mathrm{Cu}$ & $\mathrm{Fe}$ & $\mathrm{Mg}$ & $\mathrm{Mn}$ & $\mathrm{Zn}$ & $\mathrm{T}_{\text {LIQ }}$ & $\mathrm{T}^{\mathrm{AlSi}}{ }_{\mathrm{E}}$ & $\mathrm{T}^{\mathrm{AlSiCu}}{ }_{\mathrm{E}}$ \\
\hline AlSi5Cu1 & 4.85 & 1.03 & 0.14 & 0.27 & 0.01 & 0.01 & 626.6 & 572.4 & 543.6 \\
\hline AlSi5Cu2 & 5.01 & 2.06 & 0.13 & 0.25 & 0.01 & 0.01 & 622.8 & 569.2 & 534.5 \\
\hline AlSi5Cu4 & 4.89 & 3.85 & 0.13 & 0.26 & 0.01 & 0.01 & 618.3 & 562.4 & 512.5 \\
\hline AlSi7Cu1 & 7.13 & 0.96 & 0.14 & 0.28 & 0.01 & 0.01 & 613.3 & 573.1 & 526.0 \\
\hline AlSi7Cu2 & 7.05 & 1.98 & 0.13 & 0.28 & 0.01 & 0.01 & 610.0 & 569.1 & 508.0 \\
\hline AlSi7Cu4 & 6.75 & 4.38 & 0.14 & 0.28 & 0.01 & 0.01 & 604.6 & 569.3 & 509.6 \\
\hline AlSi9Cu1 & 9.16 & 1.05 & 0.14 & 0.27 & 0.01 & 0.01 & 597.3 & 572.4 & 516.3 \\
\hline AlSi9Cu2 & 9.02 & 2.44 & 0.12 & 0.27 & 0.01 & 0.01 & 589.9 & 570.2 & 506.5 \\
\hline AlSi9Cu4 & 9.45 & 4.38 & 0.14 & 0.27 & 0.01 & 0.01 & 584.4 & 566.4 & 502.8 \\
\hline AlSi11Cu1 & 10.84 & 0.94 & 0.14 & 0.27 & 0.01 & 0.01 & 579.4 & 574.5 & 509.3 \\
\hline AISi11Cu2 & 10.92 & 1.95 & 0.14 & 0.26 & 0.01 & 0.01 & 576.7 & 573.2 & 501.6 \\
\hline AISi11Cu4 & 10.55 & 4.36 & 0.13 & 0.27 & 0.01 & 0.01 & 567.7 & NA & NA \\
\hline
\end{tabular}

\section{Melting Procedure}

The alloys were melted in a reverberatory furnace. During processing, the melt was covered with a protective nitrogen gas atmosphere to prevent hydrogen and oxygen contamination. No grain refining agents were added to the melt. The ingots used were pre-modified with Sr.

\section{Thermal Analysis (TA) Procedure}

The samples with the masses of approximately $300 \mathrm{~g} \pm 10 \mathrm{~g}$ were poured into stainless steel cups. Two specially designed supersensitive $\mathrm{K}$ type thermocouples were inserted into the melt and the temperatures between $750-400^{\circ} \mathrm{C}$ were recorded. The data for TA was collected using a high-speed National Instruments Data Acquisition system linked to a personal computer. Each TA trial was repeated three times. Consequently, 36 samples were gathered in total. 


\section{Results and discussion}

Numerical solidification models have become an important tool for increasing quality and reducing the production costs of cast parts. These numerical models offer a greater potential for improving product quality and leading to a better understanding of the physics of solidification. Without accurate input data the predictions of models are meaningless. Presentl, there is a lack of accurate thermo-physical properties data for most of the Al-Si series of aluminum alloys. Therefore, the purpose of this paper was to develop a mathematical/analytical model for calculating a characteristic solidification temperature for hypo Al-Si-Cu alloys based on their chemical compositions.

In order to statistically evaluate the accuracy of equations (6-11), additional twelve alloys (see Table 2) have been chosen from the literature $[11,17-22]$. The main purpose for taking into consideration all 24 alloys (12 alloys from the literature and 12 alloys from the current experiments) was to statistically prove the reliability of the newly developed silicon equivalency concept and to check the accuracy of the newly developed equations (6-8) over a wide chemical range. All calculated liquidus temperatures are compared with the measured ones, and the corresponding statistical parameters of this data are presented in Table 3.

Table 2 - Chemical compositions (wt.\%) of Al-Si-Cu alloys and their characteristic $\mathrm{T}_{\text {LIQ }}$ and $\mathrm{T}^{\mathrm{AISi}}$ NUC, E temperatures measured using the Thermal Analysis

Tabela 2 - Hemijski sastavi (u tezinskim procentima) za Al-Si-Cu legure i njihove karakteristicne temperature $\mathrm{T}_{\text {LIQ }} \mathrm{i} \mathrm{T}^{\mathrm{AlSi}}{ }_{\text {NUC }}$ merene koriscenjem termijske analize

\begin{tabular}{|c|c|c|c|c|c|c|c|c|c|}
\hline Lit & $\mathrm{Si}$ & $\mathrm{Cu}$ & $\mathrm{Fe}$ & $\mathrm{Mg}$ & $\mathrm{Mn}$ & $\mathrm{Zn}$ & $\mathrm{T}_{\mathrm{LIQ}}$ & $\mathrm{T}^{\mathrm{AISi}}{ }_{\mathrm{E}}$ & $\mathrm{T}^{\text {AISiCu }}{ }_{, \mathrm{E}}$ \\
\hline$[17]$ & 6.823 & 1.562 & 0.10 & 0.458 & 0 & 0.01 & 613.6 & 572.3 & $\mathrm{NA}$ \\
\hline$[17]$ & 7.034 & 2.325 & 0.08 & 0.503 & 0 & 0.01 & 610.8 & 571.6 & $\mathrm{NA}$ \\
\hline$[17]$ & 7.362 & 3.693 & 0.10 & 0.491 & 0 & 0.02 & 606.7 & 568.0 & $\mathrm{NA}$ \\
\hline$[18]$ & 5.10 & 2.91 & 0.30 & 0.27 & 0.05 & 0.03 & 622.8 & 567.2 & $\mathrm{NA}$ \\
\hline$[18]$ & 5.75 & 3 & 0.31 & 0.30 & 0.05 & 0.04 & 615.7 & $\mathrm{NA}$ & $\mathrm{NA}$ \\
\hline$[19]$ & 12 & 3.39 & 0.20 & 1.55 & 0.01 & 0.03 & 565.7 & $\mathrm{NA}$ & $\mathrm{NA}$ \\
\hline$[20]$ & 6.05 & 2.99 & 0 & 0.27 & 0 & 0.03 & 614 & $\mathrm{NA}$ & $\mathrm{NA}$ \\
\hline$[21]$ & 7 & 0.003 & 0.05 & 0.35 & 0.01 & 0.02 & 612.8 & $\mathrm{NA}$ & $\mathrm{NA}$ \\
\hline$[22]$ & 9.2 & 0.01 & 0.26 & 1.28 & 0.06 & 0.06 & 592 & 576.0 & NA \\
\hline$[22]$ & 9.3 & 2.6 & 0.52 & 0.59 & 0.11 & 0.51 & 585 & 566.0 & 492.0 \\
\hline$[11]$ & 5.9 & 3.3 & 0.21 & 0.01 & 0.02 & 0.07 & 616 & 563.8 & 520.0 \\
\hline$[11]$ & 5.01 & 1.4 & 0.22 & 0.52 & 0.02 & 0.02 & 622 & 570.0 & 540.0 \\
\hline
\end{tabular}

Table 3 summarizes the following statistical parameters: multiple regression correlation coefficients $-\mathrm{R}^{2}$, standard deviation - $\sigma$, average values, minimum and maximum differences between the calculated and the 
measured temperatures. Table 3 shows that all three equations used to calculate the liquidus temperature of the Al-Si-Cu series of aluminum alloys according to the $\mathrm{R}^{2}$ criteria show acceptable predictions. The statistical analysis reveals that the application of equations (9) and (10) for the calculation of liquidus temperature results in a higher standard deviation, and more scatter in the predictions compared to the proposed model equation (6).

Table 3 - Regression coefficients, standard deviations and average values of the liquidus temperature calculated using the Silicon Equivalency Method and the method developed by other authors.

Tabela 3 - Regresioni koeficijenti, standardna odstupanjaiprosecne vrednosti likvidus temperature racunate koriscenjem silicon ekvivalentnog metoda i metoda razvijenih od drugih autora

\begin{tabular}{|c|c|c|c|c|c|}
\hline $\begin{array}{c}\text { Statistical } \\
\text { Data }\end{array}$ & \multicolumn{3}{|c|}{$T_{\text {LIQ }}$} & $T^{\text {AlSi }}$ & $T^{\text {AlsiCu }}$ \\
\hline Equation \# & $(6)$ & $(9)$ & $(10)$ & $(7)$ & $(8)$ \\
\hline $\mathrm{R}^{2}$ & 0.98 & 0.95 & 0.97 & 0.88 & 0.77 \\
\hline $\begin{array}{c}\text { Standard } \\
\text { Deviations }\end{array}$ & 2.81 & 3.89 & 3.33 & 1.39 & 7.26 \\
\hline Average Value & -1.75 & 5.75 & -2.40 & -1.07 & -0.09 \\
\hline Minimum & -5.63 & -1.96 & -8.49 & -2.96 & -14.03 \\
\hline Maximum & 2.08 & 12.33 & 2.73 & 2.77 & 10.62 \\
\hline
\end{tabular}

Equation (9) developed by Drossel is less accurate than the other two equations, (6) and (10). One of the reasons for this is the fact that this equation is valid only for the following ranges of chemical alloy compositions (expressed in weight percent): $\mathrm{Si} \leq 9.30$; $\mathrm{Cu} \leq 2.50 ; \mathrm{Mg} \leq 0.60$; $\mathrm{Fe} \leq 1.15 ; \mathrm{Mn} \leq 0.40 ; \mathrm{Zn} \leq 0.63 ; \mathrm{Ni} \leq 0.43 ; \mathrm{Ti} \leq 0.05$

Therefore, the applicability is limited to alloys that have chemical compositions falling outside of the above mentioned ranges. Vijayaraghavan's equation (10), which shows statistically better results than Drossel's equation (9), is limited because it applies only to those alloys for which $\mathrm{T}_{\text {LIQ }}$ can be estimated using only $\mathrm{Al}, \mathrm{Si}$ and $\mathrm{Cu}$ concentrations as independent variables. It fails to account for the potentially important influence of other components (e.g. Mg, Mn, Fe, Zn and Ti). Therefore, a substantial error is created in its estimate of the liquidus temperature in those cases where the components mentioned above have a considerable influence. This is evident from the fact that the equation's constant $\left(664^{\circ} \mathrm{C}\right)$ is considerably higher than the known melting point of pure aluminum $\left(660.452^{\circ} \mathrm{C}\right)$. Figs. 4,5 and 6 depict a plot of the characteristic solidification temperatures for each of the aluminum alloys presented in Ta- 
ble 1 and Table 2 versus their experimentally determined counterparts using equations (6), (7) and (8). The experimental temperatures have been measured using the Thermal Analysis technique.

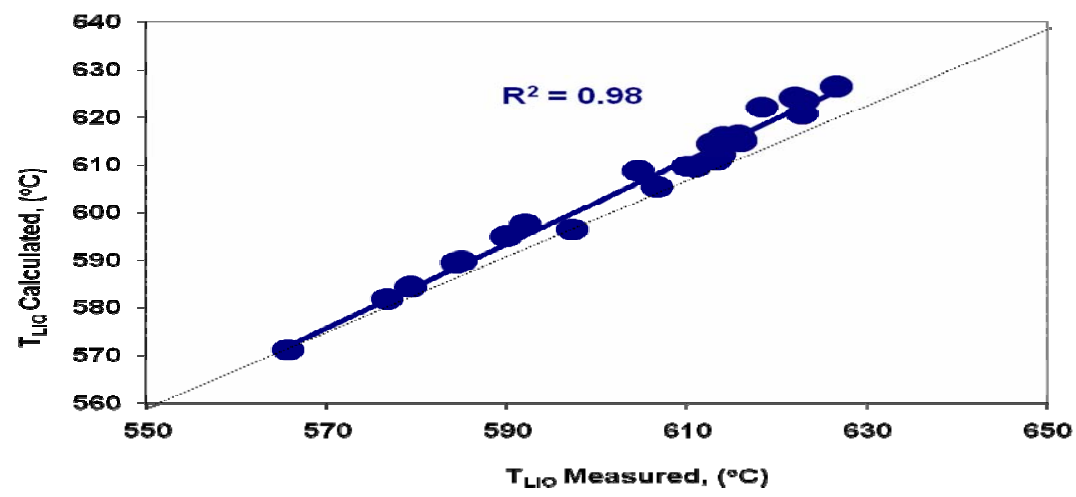

Figure 4 - Calculated versus measured liquidus temperature using equation (6) Slika 4 - Izracunate u odnosu na merene likvidus temperature koriscenjem jednacine (6)

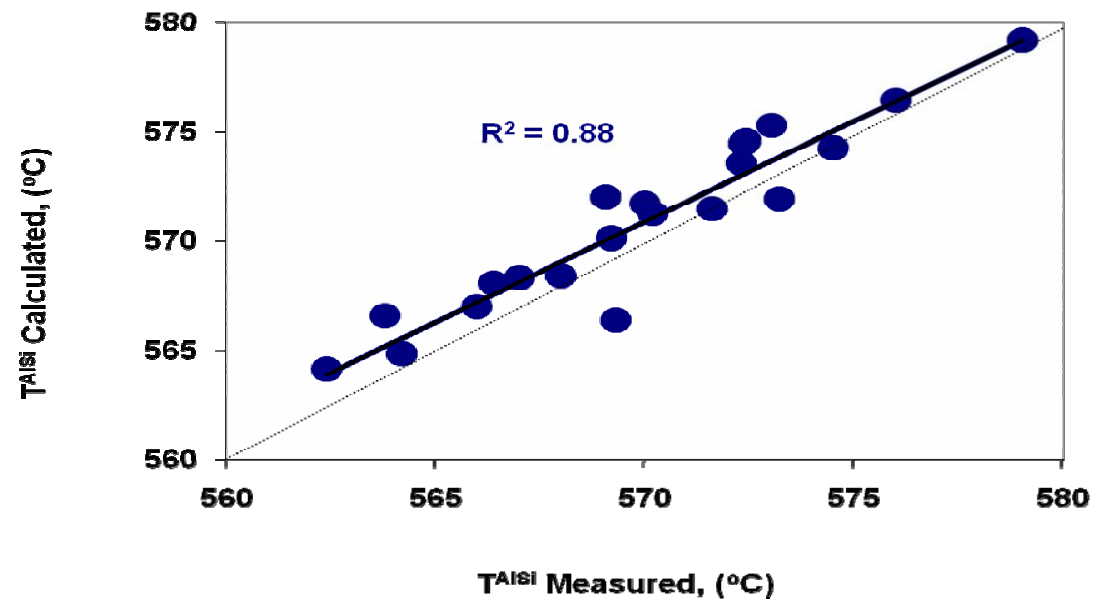

Figure 5 - Calculated versus measured Al-Si eutectic nucleation temperature using equation (7)

Slika 5 - Izracunate vrednosti u odnosu na merene Al-Si eutekticke temperature nukleacije koriscenjm jednacine (7)

The cooling curves and their first derivative have been used to determine the values of the characteristic liquidus temperatures for each particular chemical composition of alloys as presented in Table 1. For the same chemical composition the value of liquidus temperatures have been calculated using the $\mathrm{Si}_{\mathrm{EQ}}$ method. Factsage, Thermocalc and Pandat software packages have been used also to calculate the liquidus tempe- 
rature. Fig. 7 shows the comparison between the measured values of the liquidus temperature and the calculated ones obtained by applying various software packages. This Fig. 7 shows very good agreement between all applied calculating procedures.

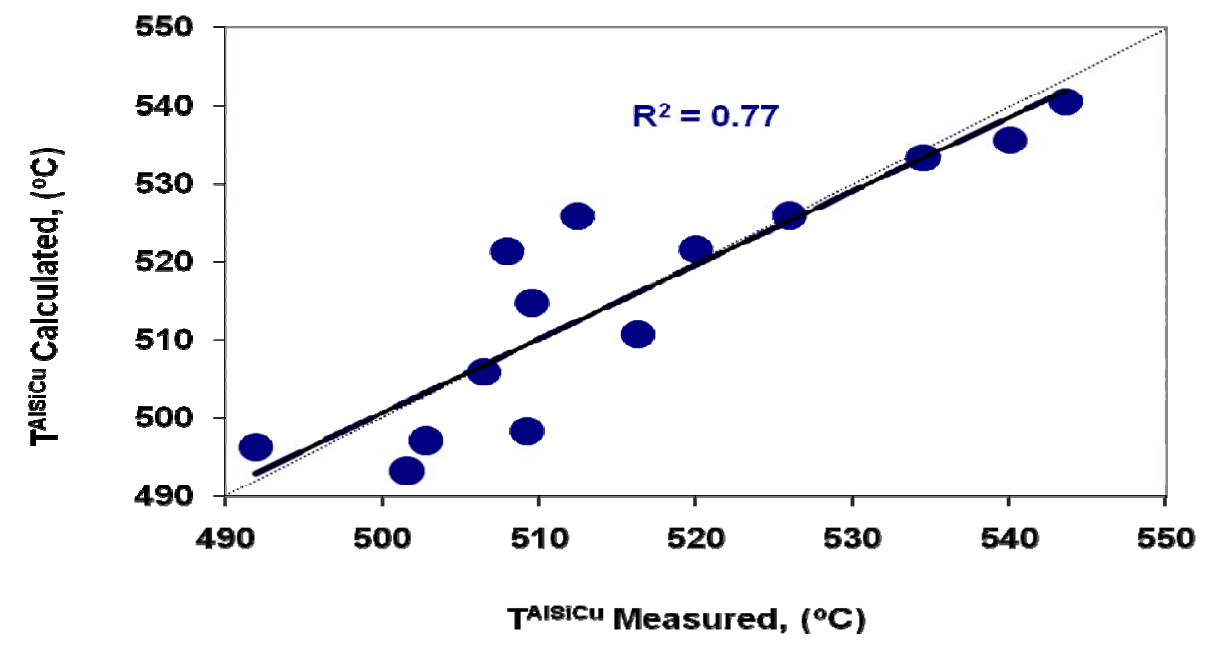

Figure 6 - Calculated versus measured Al-Si-Cu eutectic nucleation temperature using equation (8)

Slika 6 - Racunate vrednosti prema merenim Al-Si-Cu eutektickim temperaturama nukleacije koriscenjem jednacine (8)

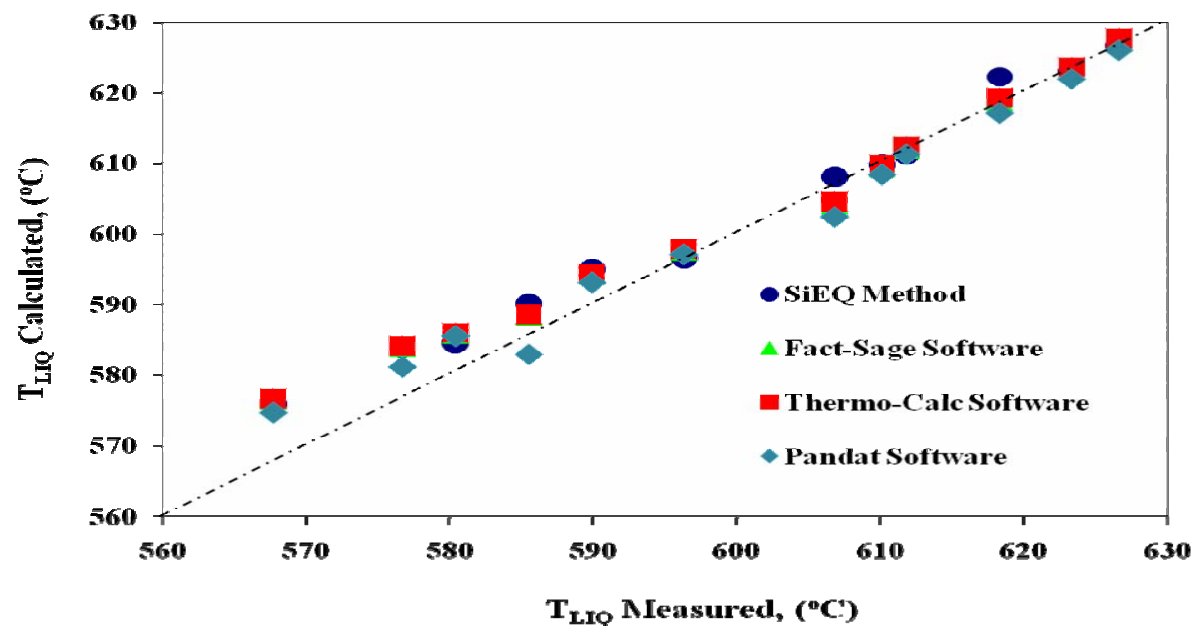

Figure 7 - Calculated versus measured liquidus temperature obtained using various analytical approaches.

Slika 7 - Racunate vrednosti prema merenim likvidus temperaturama dobijene korscenjem razlicitih analitickih pristupa 
The accuracy of the calculated liquidus temperature in the proposed model equation (6) is dependent solely on the accuracy of the coefficients, by means of which a corresponding alloy content is converted into an equivalent silicon weight percent. However, these coefficients are derived from the liquidus lines in the respective binary systems, and their reliability is closely related to the accuracy with which the liquidus curves are experimentally determined and numerically fitted. Therefore, some inaccuracy is also observed by applying this method. In order to exclude this source of error, a re-examination of the liquidus lines on the silicon rich side of the respective binary systems or even better for the ternary Al-Si-Xi system would be necessary. Another advantage of a new $\mathrm{Si}_{E \mathrm{Q}}$ method can be recognized in its application to calculate both eutectic temperatures in the Al-Si series of alloys. Potentially, a similar approach could be used to develop an equation for the calculation of the solidus temperature of aluminum multi component alloys.

\section{Application of the $\mathrm{Si}_{\mathrm{EQ}}$ procedure: calculation of the latent heat}

The latent heat of solidification is a thermo physical property of the material. During the solidification process, every substance releases a certain amount of heat that characterizes this substance. By definition, the latent heat is the energy required to solidify $1 \mathrm{~kg}$ of a liquid, expressed in $\mathrm{J} / \mathrm{g}$ or $\mathrm{J} / \mathrm{mol}$. The mathematical modeling and simulation of the process of solidification of metals and alloys is inaccurate without the knowledge of this property. Therefore, there is always a necessity to show the value of the latent heat of any alloy in advance. For pure metal a good data library is available to obtain the value of latent heat $[23,24]$. Unfortunately, there is no easy way to get the value for the latent heat of solidification of multicomponent alloys that solidify in a given temperature range (mushy zone), either using measuring techniques or calculating procedures. For all alloys which solidify in a given temperature range, the evolution of the latent heat begins at the liquidus temperature. The release of the latent heat continues until the alloy reaches its solidus temperature. In the mushy zone (the region between the liquidus and the solidus temperature), the substance is neither in a totally liquid phase nor in a totally solid phase, but is a mixture containing a fractional amount of both liquid and solid.

Several models of the latent heat release have already been proposed for modeling casting solidification. These models include the linear and quadratic releases of the latent heat between the liquidus and solidus temperatures, as well as the use of the Lever Rule and Scheil's equation [25]. Each of these models assumes that the amount of the latent 
heat released is proportional to the increase of the fraction solid in the casting. The latent heat of solidification of any alloy depends on its chemistry and the microstructure developed during the solidification process. The solidification path of these alloys was observed and the corresponding latent heat released during solidification was measured using a Differential Scanning Calorimeter (DSC).

Applying the method of silicon equivalency, the multi-component aluminum alloys can be considered as pseudo binary $\mathrm{Al}-\mathrm{Si}_{\mathrm{EQ}}$ alloys. In this case the solidification path of these alloys can be described through a formation of a primary -Al solid solution and through the precipitation of the Al-Si eutectic (secondary aluminum and primary silicon). Applying the $\mathrm{Si}_{\mathrm{EQ}}$ method, the multi-component aluminum alloys are transferred into a recognized $\mathrm{Al}-\mathrm{Si}_{\mathrm{EQ}}$ pseudo binary system. Using the Lever Rule, the amount of primary $\alpha$-aluminum can be calculated, assuming that the precipitated $\alpha$-aluminum solid solution has the same value for the latent heat of solidification as pure aluminum. Applying the same principle, the amount of secondary aluminum present in the remaining eutectic as well as the amount of primary silicon can be calculated. For non-equilibrium solidification conditions the Scheil's equation could be applied to calculate the amount of fraction solid of primary and eutectic phases.

When the latent heat has been released under the equilibrium condition, the latent heat of solidification can be calculated as follows:

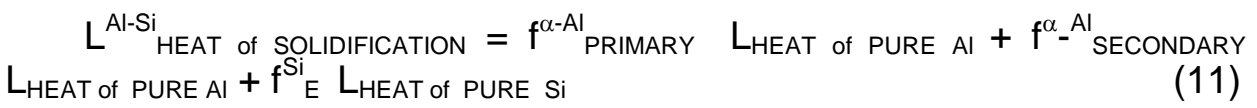

The solidification path of 12 Al alloys from Table 1 and their corresponding latent heats released during the solidification process have been also experimentally determined and measured using a Differential Scanning Calorimeter (DSC) apparatus. The latent heat of solidification has been measured taking into consideration the area between the DSC curve and the base line. This area is proportional to the latent heat energy released during solidification. For the same chemical composition, the value of the latent heat has also been calculated using the novel $\mathrm{Si}_{\mathrm{EQ}}$ method proposed in this work. Fig. 8 shows the comparison between the measured values of the latent heat of solidification and the calculated ones obtained by applying the novel algorithm for the calculation of the latent heat.

The results presented in Fig. 8 show a close agreement between the calculated and the experimental values for the latent heat. The high standard correlation $\left(R^{2}=0.9\right)$ confirms that it is possible to estimate the latent heat of the solidification of the series of Al alloys that solidified under equilibrium conditions using the novel method based on the $\mathrm{Si}_{\mathrm{EQ}}$ algorithm. 




Figure 8 - Comparison between the measured and calculated values of the latent heat for the Al alloys taken from Table 1

Slika 8 - Poredjenje izmedju merenih i proracunatih vrednosti za latentnu toplotu za legure aluminijuma preuzetih iz tabele 1

\section{Conclusions}

A novel $\mathrm{Si}_{\mathrm{EQ}}$ method has been used to calculate the liquidus temperatures of hypo multi-component aluminum-silicon alloys. The calculation procedures presented in this paper are more accurate than those found in the literature. Experiments have been carried out to observe the effect of chemistry of the series of Al alloys ( $\mathrm{Si}=5,7,9$ and $11 \mathrm{wt} \%$ and $\mathrm{Cu}=1,2$ and $4 \mathrm{wt} . \%)$ and the cooling rate $\left(6^{\circ} \mathrm{C} / \mathrm{min}\right)$ on the amount of the released latent heat during solidification. In this paper a novel method has been developed to rapidly calculate the latent heat of the solidification of the series of Al alloys. The model is based on the assumption that the latent heat of the alloy is released at the rate proportional to the formation of fraction solid during solidification. Multi-component aluminum alloys have been analyzed as pseudo binary by applying the already developed method of silicon equivalency. The results of these calculations were found to be fairly accurate in comparison to the measured values. It was noted that there is still a need for a possibility for improvement of the accuracy of the calculated latent heat values by including the effect of interaction among elements from the aluminum melt. According to the measured and calculated latent heat values for the Al-Si-Cu series of aluminum alloys, the latent heat of solidification is strongly dependent on the $\mathrm{Si}$ content and only slightly dependent on the Cu content. 


\section{References}

[1] web site: http://www.magmasoft.de/

[2] web site: http://www.thermocalc.com/

[3] web site: http://www.factsage.com/

[4] web site: http://www.esi-group.com/products/casting/procast

[5] web site: http://www.calphad.org/

[6] web site: http://www.computherm.com/pandat.html

[7] web site: http://www.rwp-simtec.de/index.php?id=12

[8] Drossel, G.; "Der Einflusse von Schmelzebehandlungen auf die Dichtheit von Gusskoerpern aus Al-Si-Gusslegierungen", Giessereitechnik, vol. 27, No. 1, p. 7, (1981).

[9] Vijayaraghavan, R., Pelle, N., Boileau, J., Zindel, J. , Beals, R.; "A Micro Model for Al-Si Alloys", Scripta Materialia, vol. 35, No. 7, pp. 861, (1996).

[10] Mondolfo, L. F.: "Aluminum Alloys, Structure and Properties", Butterworths, London pp. 213/614 (1979).

[11] Tenekedjiev, H., Mulazimoglu, Closset, B. and Gruzleski, J., "Microstructures and Thermal Analysis of Strontium Treated Aluminum Silicon Alloys", American Foundrymen's Society, Inc. Des Plaines, Illinois, 1995.

[12] ASM Handbook Volume 3: Alloy Phase Diagrams, The Materials Information Society, 1992.

[13] Kissing, R. J. and Wallace, J. F.; Refinement of Aluminum-Silicon Alloys, Foundry, April 1963, p.74.

[14] Wang, O. G. and Davidson, J. C., "Solidification and Precipitation Behavior of Al-Si-Mg Casting Alloys'; Journal of Materials Science 36, 2001, pp. 739.

[15] Barthel, J., Buhrig, E., Hein, K., and Kucl, L.; Kristallisation aus der Schmelze, VEB Deutscher Verlag fur Grundstoffindustrie, Leipzig, (1983).

[16] Djurdjevic, M. B., et al.:., 'The Effect of Chemistry and Cooling Rate on the Latent Heat Released during the Solidification of the 3XX Series of Aluminum Alloys', Materials Science Forum, March 2007, Vols. 539-543, pp. 299-304.

[17] Djurdjevic, M. B. et al., "Calculation of Liquidus Temperature for the Aluminum 3XX Series of Alloys", AFS Transactions, 1998, v. 47, 143-147.

[18] Kearney, A.; "Thermatest thermal analysis system for quality control of molten aluminum", Proceedings from the Conference on Thermal Analysis of Molten Aluminum, Rosemont, Illinois, p. 169 (Dec. 11-12, 1984).

[19] Carbonier, J. and Rechiney, C.; "Foundry monitoring of aluminum alloys using thermal analysis", Proceedings from the Conference on Thermal Analysis of Molten Aluminum, Rosemont, Illinois, p. 121 (Dec. 11-12, 1984).

[20] Winter, B. P., Ostram, T. R., Sleder, T. A., Trojan, P. K., and Pehlke, R. D.; "Mould dilation and volumetric shrinkage of aluminum alloys in green and dry sand molds" AFS Transactions, vol. 87, p.259 (1993).

[21] Lakshmanan, A. N.; "Crystallization and dissolution studies of iron intermetallics in Al-Si Alloys", Ph.D. Thesis. Universite du Quebec a Chicoutimi, (1994).

[22] Bäckerud, L., Chai, G. and Tamminen, J.; "Solidification Characteristics of Aluminum Alloys", Volume 2, AFS/SKANALUMINIUM, Oslo, 1986, 95-105. 
[23] ASM Specialty Handbook, Aluminum and Aluminum Alloys; Edited by J. R. Davis, ASM International The Materials Information Society: May 1994.

[24] web site: http://environmentalchemistry.com/yogi/periodic.

[25] Djurdjevic, M. B. et al.; "Modeling of Fraction Solid for the 319 Aluminum Alloy", AFS Transactions, 1999, vol. 14, p. 173.

\section{IZRAČUNAVANJE KARAKTERISTIČNIH TEMPERATURA OČVRŠĆAVANJA PODEUTEKTIČKIH AI-Si-CU LEGURA PRIMENOM SILICIJUM EKVIVALENTA}

\section{OBLAST: hemijske tehnologije, materijali VRSTA ČLANKA: originalni naučni rad}

Rezime:

Modeliranje procesa livenja tema je koja je poslednjih nekoliko desetina godina neprestano prisutna u livarstvu i zajedno sa brojnim softverskim paketima, koji se sve češće primenjuju u dnevnoj livačkoj praksi, dobar su pokazatelj koliki interes livačka industrija ima danas u njihovoj primeni. Većina ulaznih podataka koji se koriste u ovim modelima/softverima najčešće je izvedena iz analize odgovarajućih dvojnih, trojnih i višekomponentnih dijagrama stanja. Nažalost, osim za binarne sisteme tačnost ovih podataka, nije potvrđena kod trokomponentnih i višekomponentnih sistema. Imajući u vidu da su binarni sistemi aluminijuma prilično detaljno i tačno ispitani, napravljen je pokušaj da se bilo koji podeutektički višekomponentni sistem aluminijuma prevede u Al-Si ekvivalentni binarni sistem (u konkretnom slučaju Al-Si binarni sistem je izabran kao ekvivalentni). Pri tome je uveden novi pojam, silicijum ekvivalent (Si $\left.i_{E Q}\right)$, koji izražava uticaj bilo kog legirajućeg elementa prisutnog u leguri aluminijuma kroz ekvivalentnu količinu silicijuma. Novouspostavljeni algoritam primenjuje se za izračunavanje karakterističnih temperatura očvršćavanja višekomponentnih rastopa aluminijuma, kao i nekih njihovih termo-fizičkih osobina (npr. latentne toplote topljenja). Ovaj rad je potvrdio da se $\mathrm{Si}_{E Q}$ algoritam može koristiti za izračunavanje karakterističnih temperatura očvršćavanja kod višekomponentnih podeutektičkih Al-Si-Cu legura, kao i njihovih latentnih toplota topljenja. Statistička analiza dobijenih rezultata izračunatih primenom metode $S_{E Q} i$ izmerenih karakterističnih temperatura očvršćavanja višekomponentnih legura aluminijuma pokazala je veoma visoku korelaciju, čak i za slučaj kada su glavni legirajući elementi (Si i Cu) varirali njihove sastave u dosta širokim opsezima.

Ključne reči: Al-Si-Cu legure, silicijum ekvivalent, Binarni dijagrami stanja, Likvidus temperature, Eutektičke temperature

Datum prijema članka: 24. 10. 2011.

Datum dostavljanja ispravki rukopisa: 06. 11. 2011.

Datum konačnog prihvatanja članka za objavljivanje: 07. 11. 2011. 